\title{
КОНСТАНТИН У ЦАРСКОЈ ПАЛАТИ У СЕРДИЦИ
}

Сажетак: Овај рад се бави присуством и активностима Константина Великог у Сердици, као и у провинцијама Dacia Mediterranea, Dacia Ripensis и Thracia од 316. до 330. године н.е. Рад почиње историјским прегледом Константинових активности у региону, након чега следи археолошки преглед Сердике и других области на територији данашње Бугарске, у чијем је развоју Константин можда имао улогу. Посебно ћемо размотрити питање могуће локације царске палате у Сердици.

Кључне речи: Царска палата, Константин Велики, Сердика.

\section{Увод}

Рођен у или око Наисуса око 272. године н.е, Константин је најпознатији по подршци хришћанству, ратовима против супарничких царева и градитељским подухватима у Риму и Цариграду. ${ }^{1}$ Мало се зна о његовом одрастању и његова прича за нас почиње крајем III века када је његов отац био на месту тетрарха на северозападним територијама Царства. За време Тетрархије, Константин је провео неколико формативних година у Никомедији; такође је ишао у ратне походе за Диоклецијана и Галерија на Истоку и дуж Дунава. Годину дана након што се придружио свом оцу у Галији и Британији, Константин је проглашен за цара. Нови цезар се сместа дао на консолидовање својих снага у северозападним провинцијама и започео своју прву борбу за превласт, која је кулминирала 308. године а окончана je 28. октобра 312. године на Милвијском мосту близу Рима. Тиранин Максенције је надвладан, а Константин је додао Италију својим царским поседима. Лициније је наредне године потукао Максимина Дају, док је Галерије у међувремену умро 311. године.

Осмогодишња борба, од 316. до 324. године, између Константина и

1 Литература о Константину је обимна; класичне биографије су Baker 1931; Burckhardt 1949; MacMullen 1969; одличне савремене верзије укључују Barnes 2006 и 2011; Odahl 2004; Van Dam 2008. 
Лицинија довела је Константина до Балкана; истовремено се борио против Сармата и Гота. Прва битка против његовог новог ривала десила се октобра 316. године код Цибала, а њен исход је било Лицинијево повлачење у источну Тракију. Да би држао Лицинија на оку, Константин је у децембру презимио у Сердици. Овај рад се бави Константиновим активностима у Сердици и на територији данашње Бугарске: војним походима, градитељским подухватима у војним центрима и градовима и његовом улогом у Сердици. Кључно питање се тиче одређивања локације царске резиденције у Сердици.

\section{Константин на територији данашње Бугарске}

Не постоје непосредни наводи о Константиновом присуству на територији данашње Бугарске пре децембра 316. године (Слика 1). За време Тетрархије, Константин је био на Диоклецијановом двору у Никомедији и често је ишао у војне походе са Диоклецијаном или Галеријем. У том смислу, вероватно је да су Константин и Галерије водили битку против Сармата 294. године. Међутим, знајући где се Сармати налазе у Панонској низији, сви војни напори вероватно су били усмерени између Карнунтума, Сингидунума и Виминацијума. Константин је можда био укључен у војне походе против Гота у региону доњег тока Дунава крајем деведесетих година III века, што би га довело на територију данашње Бугарске. Поред ових епизода, често је боравио у Малој Азији и Источном римском царству до 305. године.

Након што је консолидовао своје снаге на Западу, започео изградњу и посветио већи број значајних грађевинских пројеката у Риму, Константин је у септембру 316.године боравио у Верони. Константин и Лициније су се до тада већ спремали на окршај. Прва битка између две војске догодиласе код Цибала месец дана касније, у октобру. ${ }^{2}$ Иако недостају детаљи, Константин је повео у бици, и Лициније, чија је база била у Сирмијуму, се повукао у источну Тракију, допуштајући Константину да преузме Сирмијум и затим пређе на источне ободе Dacia Mediterranea. Константинје у Сердику стигао у децембру, где је презимио припремајући се за наставак сукоба са Лицинијем. Тачан датум битке код campus Ardiensis близу Хадријанополиса није познат, али морала се десити феруара 317. године, пошто је споразум између Константина и Лицинија склопљен 1. марта у Сердици. Ово, наравно, обележава дан када су Константинови синови Крисп и Константин II били проглашени за цезаре, баш као и Лицинијев најмлађи син са Констанцијом. До јуна 317. године, Константин је био у Сирмијуму ${ }^{3}$ и можда је био ван наше територије око две године.

Царево кретање можемо лакше пратити почевши од 319. године. Одломци Теодосијевог законика смештају Константина у Сердику између новембра 319. и јануара 320. године. ${ }^{4}$ Био је у Сирмијуму ${ }^{5}$ до марта 320 . године, али се вратио у

\footnotetext{
${ }^{2}$ Barnes 1973, 36.

${ }^{3}$ CTh.11.30.7.

${ }^{4}$ CTh.2.10.1, CTh.4.12.3 и 8.16.1.2.

${ }^{5}$ CTh.6.4.1.
} 
Сердику у јуну, а онда је поново ту од децембра 320. до фебруара 321. године. ${ }^{6}$ Након тога је прешао у Сирмијум где је у марту званично прекинуо везе са Лицинијем тако што је повукао номинацију Лицинија I и II за конзуле и те године прогласио сопствене синове Криспа и Константина II за конзуле. Наредни тренутак кад можемо са сигурношћу тврдити да је цар био у Сердици је децембар 322. године. ${ }^{7}$ Током већег дела те године, Константин је био у Сирмијуму као и у средњем подунавском региону одбијајући нападе Сармата које је предводио краљ Раусимод (Rausimodus). ${ }^{8}$ Зима 322/323. године у Сердици се рано завршила када су Готи упали у регион доњег тока Дунава; Константинова војска је победила и цар је можда учврстио одбрану Римског царства у овом региону. Ово јасно није било по Лицинијевој вољи пошто је Константин практично оперисао у северној Тракији, која је припадала Лицинијевој територији. Након епизоде са Готима, Константинсе са војницима и дворјанима преселио у Солун, град који ће користити као своје главно упориште у наредних неколико година. Презимио је у Сирмијуму 323/324. године и вратио се у Солун у фебруару да се припреми за битку која ће бити његов коначни окршај са Лицинијем.

Поново сазнајемо за Константинове активности на територији данашње Бугарске током 328. године. Цар је кратко боравио у Сердици маја 328. године на путу за Рим где је ишао на Јеленину ${ }^{9}$ сахрану. Мост чију је градњу започео да би прешао Дунав из Ескуса (Oescus) завршен је јула исте године. Константин је тестирао мост са својом војском, заузимајући мали део бивших римских територија Трајанове Дакије и обнављајући тврђаву у Ромули. Последњи тренуци када можемо сместити Константина у Сердику су септембар 329. године ${ }^{10}$ и фебруар 330. године ${ }^{11}$. Константинје у Сердици провео бар 15 месеци, пре свега зими средином своје владавине, и док знамо за опште догађаје у Константиновим војним походима у оквиру овог региона, недостају многи детаљи, као што су градитељске активности.

Поред укупно више од 15 месеци проведених у резиденцији у Сердици, Константин је, такође, ишао у походе дуж Дунава и против Лицинија. У одбрани против Гота и борби против Лицинија морао је започети архитектонске радове, што за одбрану, што као награду за савезничке градове. Научници који раде у данашњој Бугарској доказали су да неколицина римских градова и војних центара има фазе које одговарају раном до средњем IV веку, али у већини случајева не постоје непосредни докази за директне интервенције овог цара. Остатак овог одељка представља један известан Константинов градитељски подухват у овом региону и неколико могућих који су под знаком питања.

Знајући за озбиљне војне интервенције против Гота у региону доњег тока Дунава, проналазак ојачаних утврђења дуж реке и друге линије одбране не би требало да буде изненађење. Константинови биографи нису били заинтересовани за

${ }^{6}$ CTh.9.3.1.1, CTh.16.10.1, CTh.2.19.2 и СТh.9.42.1.4.

${ }^{7}$ CTh.3.32.1

${ }^{8}$ MacMullan 1969, 134.

${ }^{9}$ Van Dam 2008, 52.

${ }^{10}$ CTh.12.1.16.

${ }^{11}$ CTh.16.2.7. 
детаље тако баналних догађаја као што је ратовање колико историчари раног и средњег периода царства; стога се у литератури не спомињу поименце попришта битака. Грађење ојачања на тврђавама можда није било прилика да цар стави натписе са посветама. Можемо само претпоставити да је цар наложио издрадњу одређених елемената који су археолошки смештени у период Константинове владавине. У том погледу, претпоставља се да је утврђење Дуросторум из касног римског периода Константиново дело. Штавише, гарнизон на истом месту врло вероватно потиче из Константинових подунавских похода. ${ }^{12}$ Слично томе, претпоставља се да утврђења из раног IV века и хореум у одбрамбеном гарнизону Абритус у унутрашњости припадају Константиновом периоду. ${ }^{13}$

Једини грађевински пројекат у Бугарској, такође уз Дунав, који се са сигурношћу може приписати Константину јесте бетонско-дрвени мост изграђен код Ескуса. ${ }^{14}$ Мост који је спајао Ескус са Сучидавом у данашњој Румунији, завршен је јула 328. године услед непрекидних напада Гота и других племена у дунавском региону. Константин је прешао мост са војском и поново освојио мали део Трајанове Дакије. Поново је утврдио војну базу у Ромули, око 40 км северно од Дунава. Претпоставља се да је и утврђено проширење Ескуса које датира из IV века такође из Константиновог периода.

Филипополис, смештен у јужно-централној тракијској долини, одувек је био важан град и чини се да је био још раскошнији него Сердика. ${ }^{15}$ Иако је град пао под Галеријеву па онда Лицинијеву власт, чини се да је Константин овде кратко боравио 317. године, уочи битке код campus Ardiensis. Већи број важних грађевинских пројеката може се сместити у Константинов период; да ли је цар био укључен у њих је посебно питање. Међу пројектима за које се претпоставља да Константин иницирао је и четврта и последња фаза агоре. ${ }^{16}$ Монументална Источна капија можда датира из Константиновог периода; нешто дискутабилнија је рестаурација западних купатила и зграда нове инсуле. Хронологија није тачно утврђена и неки научници истичу да су оне вероватније резултат Галеријевих градитељских подухвата. ${ }^{17}$

\section{„Сердика је мој Рим”}

Извор из касне антике под називом Anonymus post Dionem или Dio Continuatus наводи у веома кратком одељку о Константину да је цар често изјављивао „Сердика је мој Рим”. ${ }^{18}$ Овај извор се може окарактерисати као

\footnotetext{
${ }^{12}$ Ivanov 2012b, 56 .

${ }^{13}$ Ivanov 2012c, 180 и $189-89$.

${ }^{14}$ Ivanov 2012a, 7-8.

${ }^{15}$ Topalilov 2012a, посебно 372-414; и Topalilov $2012 \mathrm{~b}$.

${ }^{16}$ Topalilov 2012b, 118.

${ }^{17}$ Topalilov 2012a, 413-414.

${ }^{18}$ Müller 1851, 199.15 Constantinus. 1. Constantinus principio consilium ceperat sedem regni in urbem Sardicam transferendi; captusque eius urbis amoresemper iterabat: « Roma mea Sardica est. »2. Constantinus decessorum suorum res gestas obscurarestudens, horum virtutes jocularibus quibusdam epithetis vilipendere studebat. Scilicet Octavianum Augustum fortunae mundum appellabat, Trajanum herbam parietariam,Hadrianum
} 
анегдотски или сатиричан; стога не можемо јемчити за аутентичност ове изјаве. Без обзира у којој мери је волео и поштовао овај град, Константинје са прекидима боравио у Сердици између 316. и 323. и од 328. до 330. године, како је наведено у претходном одељку, и због тога му јебила потребна палата. ${ }^{19}$ Збиља, Атанасије, александријски бискуп, пишући о Сабору из Сердике (343. године), спомиње да је свита од неколико десетина учесника одсела у царској палати. ${ }^{20}$ Ипак, нема никаквих описа палате или назнака о њеној локацији у Сердици.

До касне антике, град Сердика се стојао се од две суседне целине ограђене зидом. Најстарији део града, основан у I веку н.е. и први пут опасан бедемом за време владавине Марка Аурелија, има површину од $166.000 \mathrm{~m}^{2}$. Отприлике $15 \%$ ове површине је археолошки истражено. Северно је био још један утврђени сектор, више него дупло већи од „Старе Сердике”, који је већим делом неубележен на картама. Научници мисле да је комплекс у оквиру старог дела града био Константинова резиденција, иако за то не постоје непосредни докази. Пре дискусије о могућој локацији царске палате у Сердики, пригодно је дати преглед познатих података о другим палатама изграђеним у периоду Тетрархије.

Величина аристократских домуса и вила у Италији и другим деловима римског света често је била импозантна, али резиденција цара је, у најмању руку, била посебна. Знамо на основу археолошких података из Помпеје, на пример, да су аристократске куће биле довољно велике да угосте породицу са слугама, док Катон Старији пише да је поред породице потребно око 15 чланова послуге како би се опслужила вила. ${ }^{21}$ Докази из касног римског домуса у Ostia Antica указују на сличан образац у ком породице живе са слугама. Док је „Августова кућа” (Domus Augusti) на Палатину била доста скромна, у њој је и даље могла да се смести царска породица са слугама. За разлику од ње, научници процењују да су Флавијанова палата у Риму и Хадријанова вила у Тиволију могле да приме стотину или више људи. Под владавином Марка Аурелија, цар више није имао луксуз дугорочног пребивања у Риму или на неком имању ван града. Од шездесетих година II века цар је чешће био у пограничним регионима царства са армијама, бранећи Римско царство од непријаља у суседству, а касније бранећи себе од својих противника.У том контексту, цар би био стациониран у сталној тврђави, као што је Карнунтум, или у привременим логорима на терену. Цареви из средњег периода царства и њихове породице имали су имања, али тек је од доба Тетрархије изграђен талас палата у новим управним градовима или у местима где би цареви одабрали да се повуку из службе. У овом периоду, царска палата више није служила само у луксузне и државне сврхе; цар је имао велику војну пратњу у ово време превирања, а то су били војници којима је требало обезбедити касарне, храну и друге потрепштине. Царска свита је често бројала и по неколико хиљада људи.

Палата у Антиохи, коју је изградио Диоклецијан, а дорађивали каснији

\footnotetext{
pictoriam officinam, Marcum ridiculum, Severum...

${ }^{19}$ Аутор новијег издања о Сердики износи идеју да су Хелена и/или Константин можда били рођени у самој Сердици или њеној околини (Vachkova 2012, 73-89).

${ }^{20}$ Historia Arianorum 15,5.

${ }^{21}$ de Agri Cultura 10 and 11.
} 
цареви, није добро позната пошто њени остаци леже дубоко испод модерног града. ${ }^{22}$ Најбољи подаци се налазе у делима Либануса који расправља о „новом граду” на речном острву близу хеленског града. Либанус наводи да је палата била опасана зидинама, а изнутра организована као гарнизон, са улицама са две колонаде и четворокраким луком на раскршћу. Палата је, према наводима, била у непосредној близини хиподрома.

Напознатија од палата из периода Тетрархије је Диоклецијанова велика резиденција у Сплиту. ${ }^{23}$ Овај комплекс у облику заобљеног правоугаоника налази се унутар масивних зидина са путевима који се укрштају у војном стилу. Дуж зидина у северној половини палате налазе се одаје које су налик касарнама где би боравили војници и слуге. Ови северозападни и североисточни сектори су имали дворишта у центру са простором за одлагање и, вероватно, кување и обедовање. Најисточнији део комплекса дуж зидина ка моруслужио је као стамбена област и такође је садржао две базиликалне церемонијалне дворане. Пре стамбене зоне су се још налазили и маузолеј и наспрам њега храм.

Први пут употребљена од стране Констанција Хлора, а касније и Константина и његових синова, палата у Триру била је кључни управни центар. ${ }^{24}$ Иако целокупан план ове палате није потврђен, са неколицином делова смо добро упознати. Добро очувана базилика, изграђена од опеке, служила је као сала за аудијенције са резиденцијалним делом на северу. На југу, бар судећи по плану, налазио се комплекс царских купатила, који је у доброј мери очуван. Трагови хиподрома су пронађени североисточно од купатила. Град је био опасан масивним бедемом, о чему сведоче Црна врата (Porta Nigra); међутим, чини се да нема унутрашњих одбрамбених зидова који раздвајају град од просторија палате.

Царска палата у Сирмијуму је, такође, добро позната захваљујући напорима српских и америчких археолога. ${ }^{25}$ Палата која се налази у најјугоисточнијем делу Сирмијума, и њој суседни хиподром, на северу, изграђени су у касном III или раном IV веку и поклапају се са владавином Диоклецијана и Константина, који су обојица ту провели доста времена; палата показује знаке дораде у току позног IV века. Хиподром је испитан сондажним археолошким истраживањима, док су се делови палате испитивани и сондирањем и истраживањем у широком ископу у делу који је недавно рестауриран и сачуван у оквиру наткривеног објекта (музејске поставке). Ово велико подручје ископавања садржи унутрашње двориште са перистилом, апсидалну дворану и припојене одаје. Складишне просторије се налазе западно од палате. Да би се цар заштитио, првобитни бедемски зид је ојачан и изграђен је унутрашњи бедем како би се палата одвојила од осталог дела града.

Једна од најважнијих палата с аспекта управљања, она у Солуну, такође је проучавана упркос томе што њен већи део лежи испод данашњег града. ${ }^{26}$ Зна се за

\footnotetext{
${ }^{22}$ Downey 1963, 117-19; Ćurčić 1993, 68-69.

${ }^{23}$ Ward-Perkins $1970,454-59$.

${ }^{24}$ Ward-Perkins 1970, 442-49.

${ }^{25}$ Recently, Jeremić 2009 and Werner 2010.

${ }^{26}$ Ward-Perkins 1970, 449-54.
} 
неколико компоненти палате, а најпознатија од њих је црква Светог Ђорђа, која је првобитно можда требало да служи као маузолеј. Пут са колонадом води на југ до пута Егнација (Via Egnatia), а јужно од њега се налази хиподром. Хиподром се на западу граничи са низом грађевина, укључујући једну апсидалну дворану за пријеме, унутрашње двориште са чије су стране биле мале одаје и велику просторију под куполом који је припадао комплексу купатила. На месту где се укрштају пут Егнација и путеви који воде у различите делове палате налази се Галеријев славолук.

Коначно, Галеријева велика палата у Ромулијани је, можда, најдетаљније истражена од свих тетрархијских палата, с обзиром на то да се налази на руралном истоку Србије. ${ }^{27}$ Галеријева палата је окружена издржљивим зидинама са масивним кружним кулама. Унутрашње уређење ни по чему не наличи војном систему. Пут између једине две капије близу средине западног и источног зида раздваја ,јавни” и „приватни” простор палате. На југу, у „јавном” сектору, налазе се складишне просторије, велики комплекс купатила, храм и друге грађевине. Стамбени комплекс се, изгледа, налази у североисточном углу палате, док је централни и западни део северне половине палате испуњен низом церемонијалних и рекреативних простора. На брду источно од палате се налазе хумке где су сахрањени цар и његова мајка.

Упркос свим разликама, постоји доста заједничких образаца и компоненти. Све палате осим Ромулијане и Сплита биле су смештене у контекст градова и опасане дебелим бедемима. Палате у Сплиту и Ромулијана налазиле су се унутар масивних зидина, док су се друге ослањале на градска утврђења, у неким случајевима са сегментима који су додати првобитном одбрамбеном систему. Све имају приватне и јавне просторе, укључујући апсидални атријум. Димензије палата варирају и иду од скромних $31.000 \mathrm{~m}^{2}$ палате у Сплиту до палате у Солуну која се простире на површини од око $120.000 \mathrm{~m}^{2}$; половина има уређење војног типа са укрштеним путевима. Четири од шест палата су смештене одмах надомак циркуса, док таква конструкција не постојиу палатама у Сплиту и Ромулијани.

Ако се вратимо у Сердику и замислимо Константина како борави тамо са пратњом која броји хиљаде, укључујући војнике, могућа локација царске резиденције могла би се налазити у позно античком делу Сердике (Слика 2). Као што је горе напоменуто, „Стара Сердика” (Сердика I) има површину од око 16,6 хектара и била је први пут утврђена за време владавине Марка Аурелија, према сведочењу археолошких показатеља и добро очуваних натписа; ${ }^{28}$ у раном/средњем IV веку је дошло до обнављања градског зида и накнадних поправки, али без јасне фазе из Константиновог периода (Слика 3). Још један бедем (Сердика II), са кружним кулама, саграђен је северно од „Старе Сердике” у позном античком периоду, утростручавајући величину града. ${ }^{29}$ Веома је мало археолошких сазнања о грађевинама унутар зидина овог „новог” дела Сердике, али у „Новој Сердици” је било обиље простора за чланове царског двора па чак и хиподром. Научници као

\footnotetext{
${ }^{27}$ Recently, Vasić 2006 and Popović 2011.

${ }^{28}$ Stancheva 1975.

${ }^{29}$ Kirin 2000, 262-69; Kirova 2012, 206-08.
} 
што је Кирова (2012), међутим, истичу да „Стара Сердика” садржи пре свега јавне зграде и да су зидови „Нове Сердике” можда били изграђени око дела који је био незаштићена стамбена област. Но, како је ово био гигантски подухват, чини се вероватним да је његову градњу започео цар.

Још једна хипотеза се заснива на недавним, необјављеним, ископавањима. Површина од око $20.000 \mathrm{~m}^{2}$ у североисточном делу „Старе Сердике” није била детаљно истражена. Поред низа зидина чија намена није утврђена, зна се за део купатила у близини живог извора топле минералне воде. Од купатила из римског периода ту је осмоугаона одаја поплочана мармером и незнатно већа од ротонде Светог Ђорђа; надомак ње се налази полукружни базен. У Отоманском периоду, купатила су рестаурирана и изграђена је џамија Бања Баши. Недавна ископавања „Западне капије” открила су велику хришћанску базилику (процењена дужина је 30 м) са подним мозаицима, који по прелиминарним проценама на основу датовања новчића $^{30}$ потичу из Константиновог времена. Базилика се налази на неких 20 м северно од комплекса купатила и лежи над двема инсулама и одељцима пута, што указује на важност ове базилике.

Иако нису доступни никакви непосредни докази, већина научника, међутим, сматра да су све или неке од грађевина у централноисточним и југоисточним секторима „Старе Сердике” служиле као резиденција царева Галерија и Константина (Слика 4). Грађевине, од којих све имају фазу раног IV века, ископане су педесетих година XX века када је нова социјалистичка власт под Георгијем Димитровим изградила низ управних зграда. Било је и накнадних археолошких радова мањег обима. Многи од остатака су уништени у XX веку или остају недоступни испод модерних грађевина. Једна област је добро позната и представља важну туристичку атракцију у Софији, наиме ради се о архитектонским остацима који окружују цркву ротонде Св. Ђорђа; даље према југу су остаци која указују на елитну резиденцију, купатило и неке, претпоставља се, комуналне грађевине.

Смештена у унутрашњем дворишту између Председничке палате и хотела Шератон, лежи црква ротонде Св. Ђорђа, једна од знаменитих споменика Софије (Слика 4, бр. 4). ${ }^{31}$ Ова црква од опеке, посвећена средином V века, јесте преуређен калдаријум (caldarium) комплекса купатила из раног IV века. Купатило пак лежи изнад инсуле из II - III века. Купатилима се прилазило из кардо максимуса (cardo maximus) и улазило се у затворено двориште, које је можда служило као палестра. Унутрашњи распоред купатила је симетричан и прати осу запад-исток. Из палестре се улазило у велику правоугаону одају са крајевима у виду апсиде, око 20 х 13м. Како је ово први простор после дворишта и нема видљивих фонтана, чини се да је ово служило као вестибил за главни улаз. Даље на југ, наредна одаја је отприлике квадратна са заобљеним угловима и правоугаоним продужецима на северним и јужним крајевима са базенима; недостатак хипокауста указује на то да је ово био фригидаријум (frigidarium). Све три мале одаје на оси север-југ су имале грејање,

\footnotetext{
30 Лична преписка са Др. Тодором Чобановим, Заменик градоначелника, Општина Софија; ископавања код „Западне капије" финансирала је Општина Софија а под руководством су Илијане Борисове и Андреја Алаџова.

${ }^{31}$ Ivanov and Bobchev 1964, 17-20; Venedukov and Petrov 1964; Kirin 2000, 157-256; Kirova 2012, 227-29.
} 
централну су научници означили као тепидаријум (tepidarium), а за мање се претпоставља да су служиле као свлачионице (apoditeria). Ротонда, калдаријум, има четири апсидалне нише са лако препознатљивим стубићима хипокауста. Северно и јужно од ротонде, повезан са просторијама за које се претпоставља да су биле свлачионице налази се и пар правоугаоних соба са лучним завршецима, такође са грејањем. Источно од источног бедема купатила је пут који иде са севера на југ.

Источно од овог пута је још један монументални комплекс, који се такође простире са запада на исток, са неколико фаза из позне антике (Слика 4, бр. 5). ${ }^{32}$ Ми смо, наравно, заинтересовани за фазу раног IV века. Због дорада из V, и могуће VI века, као и због скорашњих ,рестаурација” за посетиоце, ову грађевину није једноставно описати. Има осам главних одаја. Смештена надомак пута и паралелно са њим налази се дугачка конструкција са неколико степеника, која је можда била портикус. Данас постоји само један улаз у зграду из грађевине са степеницима, који води у велику базиликалну дворану у оквиру које археолози верују да су била два реда са по три стуба. Када се прође право између редова стубова, улази се у апсидалну одају са осмоугаоним атријумом. Јужно се налази мала апсидална одаја. Дуж јужних граница локалитета су три одаје у истој линији са системом хипокауста. Зграда се протеже на југ испод садашњег плочника; изгледа да се ходник на југостоку грађевине наставља јужно од „зграде са ротондом”. У неком тренутку у позној антици или у средњем веку додата је мала одаја, саграђена од сполија, у северозападном углу, поред, али без приступа путу, лежећи преко једног дела претпостављеног портикуса.Ова одаја је на нивоу портикуса и просторије у коју се улази из базиликалне дворане; има четири мале лучне нише и кружни отвор у западном зиду и још два кружна отвора у северном зиду. Намена ове собе није јасна.

„Зграда са ротондом” нам је позната, али (?) није добро документована (Слика 4, бр. 7). ${ }^{33}$ Чини се да припадавећем комплексу који почиње близу источног зида Сердике и завршава се код јужног продужетка кардо максимуса. У најзападнијем одељку се налази низ великих правоугаоних одаја. Источни део има четири дугачка, паралелна зида са запада ка истоку; на источном крају су два паралелена зида која се протежу према згради са апсидалном двораном. Такође на источном крају је и кружни елемент пречника око 10 м. Само половина ове ротонде је ископана. У археолошкој евиденцији Сердике до следећег познатог елемента на југу постоји водоравни размак од око 20 м.

Остаци још једне, наизглед идентичне ротонде, откривени су јужно од горе поменуте. ${ }^{34}$ Ископани остаци су на растојању од око 20 м; међутим, размак између целих ротонди је био око 15 м. Та јужна ротонда је продужетак велике грађевине означене као „резиденција испод Корекома” (Слика 4, бр. 8). Ова стамбена зграда није у потпуности ископана и површина од отприлике 40 х 35 м одаје устисак раскоши. Највећи простор је површине око 28 х 17 м и сматра се да је служио као перистил; поплочан је мозаиком, иако је само мали део пода остао нетакнут.

\footnotetext{
${ }^{32}$ Stancheva 1994, 58-61; Kirin 2000, 302-07; Kirova 2012, 226-27.

${ }^{33}$ Kirin 2000, 307-309.

${ }^{34}$ Stancheva 1994, 61-63; Kirin 2000, 310-14; Kirova 2012, 229-30.
} 
Северно одатле је низ правоугаоних соба са остацима грејног система; на западу је било велико, делимично ископано унутрашње двориште. Источни крак је оивичен паром ходника који се кроз улаз спајају на свом краћем крају; поплочани су разнобојним мозаицима. Коначно, на југу се налази низ од пет одаја - на крају су собе неправилног облика, централна одаја је осмоугаона и повезана са „перистилом”, док су две собе између кружне. Ове две су поплочане разнобојним мозаицима. Зграда се очигледно наставља на север, југ и запад.

После још једног водоравног размака од око 20 м у археолошкој евиденцији налази се комплекс који укључује мало купатило, ископано педесетих година XX века које није добро документовано (Слика 4, бр. 9). ${ }^{35}$ Западни део ове зграде састоји се од издуженог атријума са редом стубова који нису постављени централно. Северно и јужно су мале собе а источно је већа, правоугаона одаја. Иако за то нема доказа, распоред овог простора подудара се са малом касарном или гостинском собом, као што је хоспиталија у Хадријановој вили у Тиволију. Мање одаје се могу сматрати спаваћим собама, а источна одаја триклинијум (triclinium). Источни део ове зграде је балнеум (balneum) и нема доказа да је постојао директан пролаз који је спајао два одељка. Чини се да се улазило са севера у ходник који је ишао са запада ка истоку и који је делимично ископан. Врата на јужном зиду водила су у правоугаону собу са богато украшеним подом који се састојао од мозаика и opus sectile. Јужно је још једна правоугаона соба са малом фонтаном. Из „собе са мозаиком" су врата на источном зиду водила у осмоугани калдаријум, који има неправилан образац ниша: две велике апсидалне нише, једна мала апсидална ниша и велика правоугаона ниша. Мала врата на северозападном зиду воде у ходник који се спаја са најсевернијим ходником са запада ка истоку.

Поред ових важних елемената ту су и архитектонски елементи на крајњем југоистоку Сердике и западно од комплекса хоспиталија/балнеум. Потоњи је можда био наставак хоспиталије. Претходни је могуће имао комуналну или стамбену функцију (Слика 4, бр. 10).

Нема никаквих трагова хиподрома или маузолеја. Потоњи није проблематичан пошто нису све тетрархијске резиденције имале маузолеј. Галерије је планирао да буде сахрањен у Ромулијани, а Константинје имао у плану Рим и, касније, Цариград за место свог вечног починка. Од функционалних управних палата, Трир, Сирмијум, Антиохија и Солун су сви имали хиподроме; Максентијева вила и Цариград су такође имали хиподром. Одсуство хиподрома у Сердици можда просто указује на то да археолози још нису открили његову локацију, или да хиподрома није било. Као што је претходно указано, „Нова Сердика” је имала обиље простора за хиподром; научници су такође указали на то да се хиподром можда налазио на релатино равном простору источно од града. Међутим, имајући на уму да је Константин релативно кратко боравио у Сердици и за то време био концентрисан на Лицинија, хиподром можда није ни био изграђен. Уместо тога, цар је можда користио амфитеатар саграђен у II веку и смештен свега 250 м источно од „Старе Сердике” дуж непосредног предграђа у наставку декуманус максимуса (decumanus

${ }^{35}$ Stancheva 1994, 60-61; Kirin 2000, 314-19; Kirova 2012, 230. 
maximus). ${ }^{36}$ Амфитеатар би и даље омогућио цару да поздрави грађане и да оркестрира поворке које улазе у Сердику.

Упркос недостатку ова два елемента, многи архитектонски простори описани овде поклапају се са типом компоненти нађених у другим тетрархијским палатама. Величина и раскош стамбеног простора достојна је цара. Оно што је можда била дворана за пријеме, источно од купатила Св. Ђорђа, иако малена, била је функционална просторија. Елемент који је овде назван хоспиталија/балнеум била је кључна компонента - без обзира да ли је била намењена сталним становницима или гостима. Распореди купатила су донекле проблематични. С једне стране, чини се да је балнеум заправо био повезан са „резиденцијом испод Корекома”; дакле, био је приватно купатило. Оно веће, купатило „Св. Ђорђа”, није повезано ни са једном просторијом описаном у овом тексту, али га треба посматрати као јавно купатило пошто је улаз био из кардо максимуса. Одређена поређења, на пример, са Цариградом и Сплитом, су неприкладна, међутим када упоредимо остатке у североисточном сектору Сердике са архитектуром царске палате у Сирмијуму (укупна величина и елементи), има много сличности. Док археолози који радеу Софији не буду открили епиграфске или друге конкретне доказе, идеја да је североисточни сектор Сердике служио као Константинова царска резиденција остаје у домену нагађања.

\section{Сажетак}

Иако без коначних закључака, овај рад прати Константинов траг на територији данашње Бугарске, предлаже доказе о градитељским подухватима дуж реке Дунав и у неким војним центрима и градовима у унутрашњости, и подржава општеприхваћену представу да је југоисточни регион Сердике служио као царска резиденција.

Константинје играо важну улогу у региону модерне Бугарске а регион је играо важну улогу у консолидацији његове моћи. Dacia Mediterranea, Thracia и Dacia Ripensis биле су стратешки смештене између Запада и Истока и између Римског царства и варварских земаља. С обзиром на околности својих обрачуна са Лицинијем, црквом и западним делом царства, Константин је често био у покрету; боравио је у Сердици најмање 15 месеци, пре свега током зима 316/17 - 322/23. Научници су открили доказе о фазама из раног IV века широм ове територије; међутим, свега неколико је засигурно изградио Константин. Током својих похода против Гота, знамо за изградњу моста преко Дунава код Ескуса 328.године. Неколицина могућих грађевинских пројеката је укратко описана, поготово градитељски подухвати у главним војним центрима као што је Дуросторум и Абритус. Раскошни град Филипополис такође има већи број фаза из раног IV века; међутим, недостају нам директне везе са Константином.

У писму које се тиче Сабора у Сердици (343. године н.е.), Атанасије Александријски спомиње царску палату; остаје питање: где се налазила

\footnotetext{
${ }^{36}$ Kirova 2012, 233-37.
} 
резиденција? Постоји неколико делова у оквиру „старе” и „нове” Сердике који су довољно пространи да се у њих смести резиденција за царски двор. Само један од ових делова, наиме, југоисточни одељак „Старе Сердике”, значајније је истражен. Овај део града од око $29.000 \mathrm{~m}^{2}$ има многа обележја царске палате: два купатила, церемонијални простор, богато уређене одаје дневног боравка, складишни простор и део за послугу или дворјане. На основу тренутно доступних доказа, ово је највероватнија локација царске палате у Сердици. Услед потешкоћа приликом ископавања унутар насељеног дела Софије, везе између гореописаних структура нису јасне; штавише, недостаје нам епиграфских или других доказа из литературе који би могли повезати Константина са овим делом Сердике.

\section{Захвалница}

Аутор је захвалан организаторима и спонзорима конференције „Константин, Сирмијум и ранохришћанство": гђи. Даници Драгичевић Ђукић (директорица Музеја Срема), професору Ненаду Лемајићу (Одсек за историју на Универзитету у Новом Саду), гђи. Биљани Лучић (Завод за заштиту споменика културе, Сремска Митровица), поштованом господину Браниславу Недимовићу (градоначелник Сремске Митровице), господину Љубиши Шулаји (директор Завода за заштиту споменика културе, Сремска Митровица) и његовој екселенцији Епископу сремском, Василију. Хвала особљу у АИЦ: Бојани Бојановој, Антону Казакову, Емилу Нанкову, Елици Поповој; посебно хвала Димитрини Поповој, која је осмислила илустрације за овај чланак, и Доротеји Валентиновој, која је пронашла важне секундарне изворе.

Аутор је посебно захвалан професору Мајклу Вернеру, који је Де Сену давно упознао са историјом Рима на Универзитету у Олбанију и позвао га да учествује на конференцији у пријатном граду Сремској Митровици, и гђи. Слободанки Вернер, која је предводила Де Сену и истраживаче АИЦ на незаборавном обиласку археолошких налазишта у Србији октобра 2012. године. 


\section{Литература:}

Baker, G.P. (1931), Constantine the Great and the Christian Revolution, London.

Barnes, T.D. (1973), "Lactantius and Constantine," J. Roman Studies 63, 29-46.

Barnes, T.D. (2006), Constantine and Eusebius, Harvard University Press.

Barnes, T.D. (2011), Constantine: Dynasty, Religion and Power in the Later Roman Empire, WileyBlackwell.

Burckhardt, Jacob (1949), The Age of Constantine the Great, Routledge.

Ćurčić, Slobodan (1993), "Late Antique Palaces: the Meaning of Urban Context," Ars Orientalis 23, 67-90.

Downey, Glanville (1963), Ancient Antioch, Princeton University Press.

Ivanov, Rumen (2012a), "Colonia Ulpia Oescensium", in R. Ivanov ed. (2012), Corpus of Ancient and Medieval Settlements in Modern Bulgaria, Vol 1: Roman Cities in Bulgaria, Prof. Marin Drinov Academic Publishing House (Sofia), 1-44.

Ivanov, Rumen (2012b), "Durostorum - casta, canabae, municipium, vici," in R. Ivanov ed. (2012), Corpus of Ancient and Medieval Settlements in Modern Bulgaria, Vol 1: Roman Cities in Bulgaria, Prof. Marin Drinov Academic Publishing House (Sofia), 45-108.

Ivanov, Rumen (2012c), “Abritus," in R. Ivanov ed. (2012), Corpus of Ancient and Medieval Settlements in Modern Bulgaria, Vol 1: Roman Cities in Bulgaria, Prof. Marin Drinov Academic Publishing House (Sofia), 155-198.

Ivanov, T. and C. Bobchev (1964), "Разкопки върху площта на хотел Балкан в ценъра на София през 1952-1953 г.," inСердика. Археологически, Материали, Ипроучвания, 1, 9-76.

Jeremić, M. (2009), "The Sirmium Imperial Palace Complex in the light of recent archaeological investigations," in N. Cambi, J. Belamarić and T. Marasović (eds.) Diocletian, Tetrarchy and Diocletian's Palace on the 1700th Anniversary of Existence, Split, 471-499.

Kirin, Asen E. (2000), The Rotunda of St. George and late antique Serdica: from imperial palace to Episcopal complex, $\mathrm{PhD}$ Thesis for Princeton University.

Kirova (2012), "Serdica", in R. Ivanov ed. (2012), Corpus of Ancient and Medieval Settlements in Modern Bulgaria, Vol 1: Roman Cities in Bulgaria, Prof. Marin Drinov Academic Publishing House (Sofia), 199-260.

MacMullen, Ramsay (1969), Constantine, Harper and Row Publishers.

Müller, C. (1851), Fragmenta Historicorum Graecorum, vol. 4, Ed. Ambrosio Firmin Didot.

Odahl, Charles Matson (2004), Constantine and the Christian Empire, Routledge.

Popović, Ivana (2011), Felix Romuliana - Gamzigrad, Institute of Archaeology, Belgrade.

Stancheva, Magdalina (1994),“ЗаКонстантиновиякбарталвСердика,”Сердика, Средеи, София 2, 53-80.

Stancheva, Magdalina (1975), "Втори наднис за крепоцтата стена на Сердика”, Археология 17.3, 30-35.

Topalilov, Ivo (2012a), "Philippopolis," in R. Ivanov ed. (2012), Corpus of Ancient and Medieval Settlements in Modern Bulgaria, Vol 1: Roman Cities in Bulgaria, Prof. Marin Drinov Academic Publishing House (Sofia), 363-438.

Topalilov, Ivo (2012b), Римският Филипопол 1. Топография, градоустройство и архитектура, Издателство Фабер.

Vachkova, Vesselina (2012), Serdica is My Rome, Sofia.

Van Dam, Raymond (2008), The Roman Revolution of Constantine, Cambridge University Press.

Vasić, Miloje (2006), Felix Romuliana: 50 Years of Archaeological Excavations, Institute of Archaeology, Belgrade. 
Venedukov, I. and T. Petrov (1964), “Цьрквата Св. Георги в София,”inСердика. Археологически, Материали, Ипроучвания, 1, 77-108.

Ward-Perkins, J.B. (1970), RomanImperialArchitecture, YaleUniversityPress.

Werner, Michael (2010), Sirmium. Imperial Palace Complex, Institute for Preservation of Cultural Monuments, Sremska Mitrovica. 


\section{СЛИКЕ}

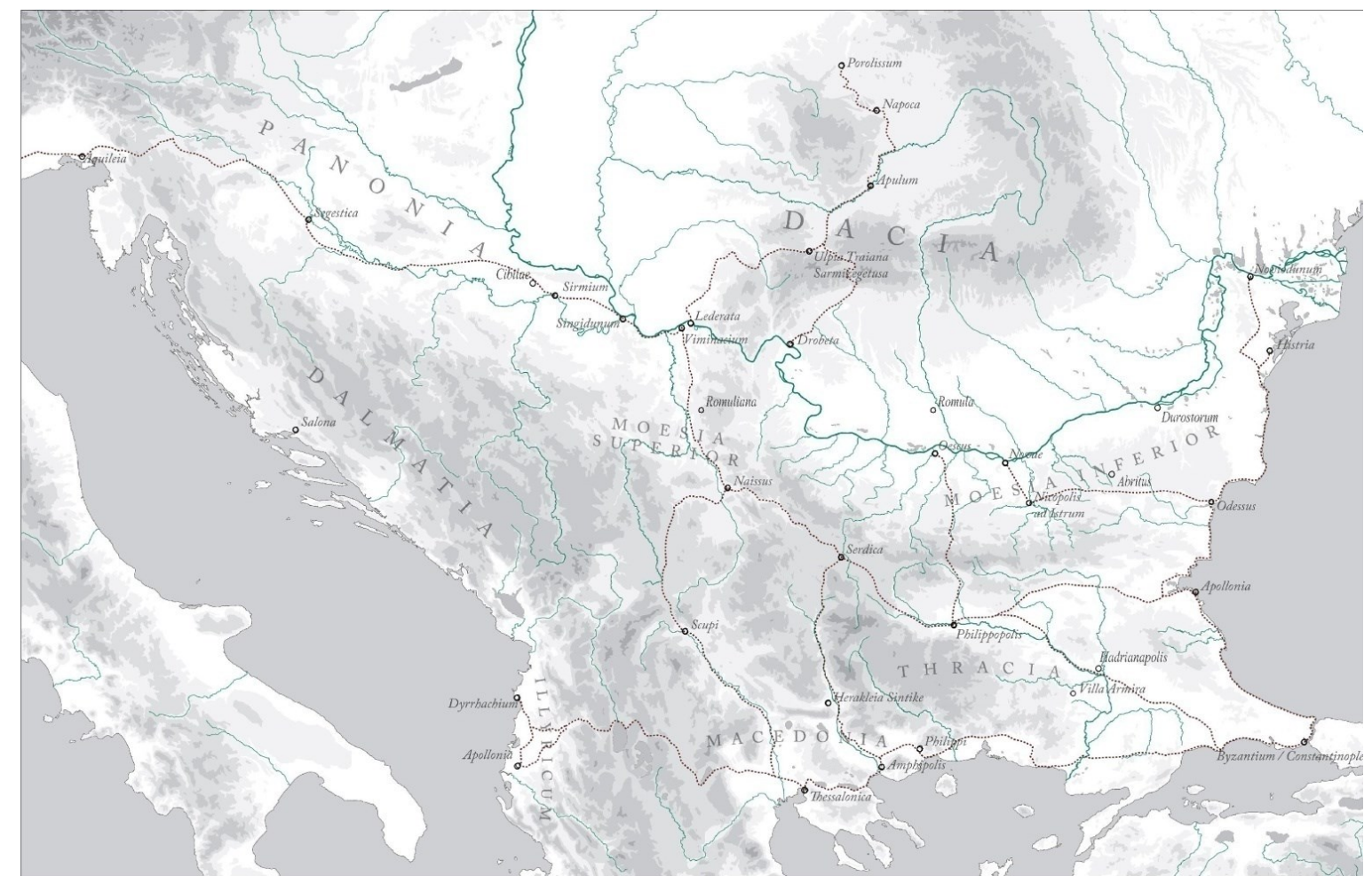

Слика 1. Карта Римског Балкана

(аутор Чавдар Цочев, са дорадама Димитрине Попове) 


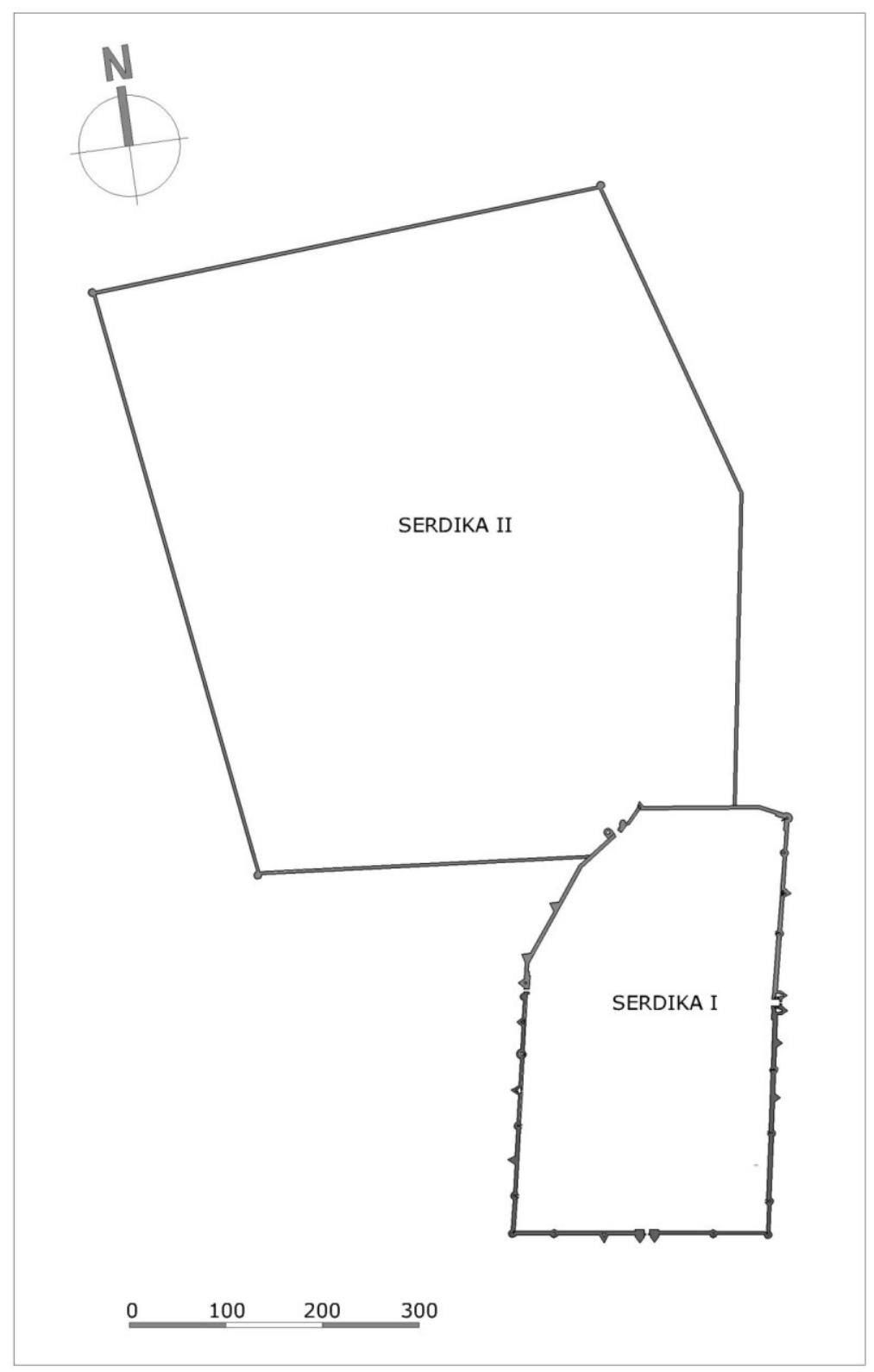

Слика 2. Карта са Сердиком I (,старом”) и II(„новом”)

(аутор Димитрина Попова према Бојаџив 1959, слика 8) 


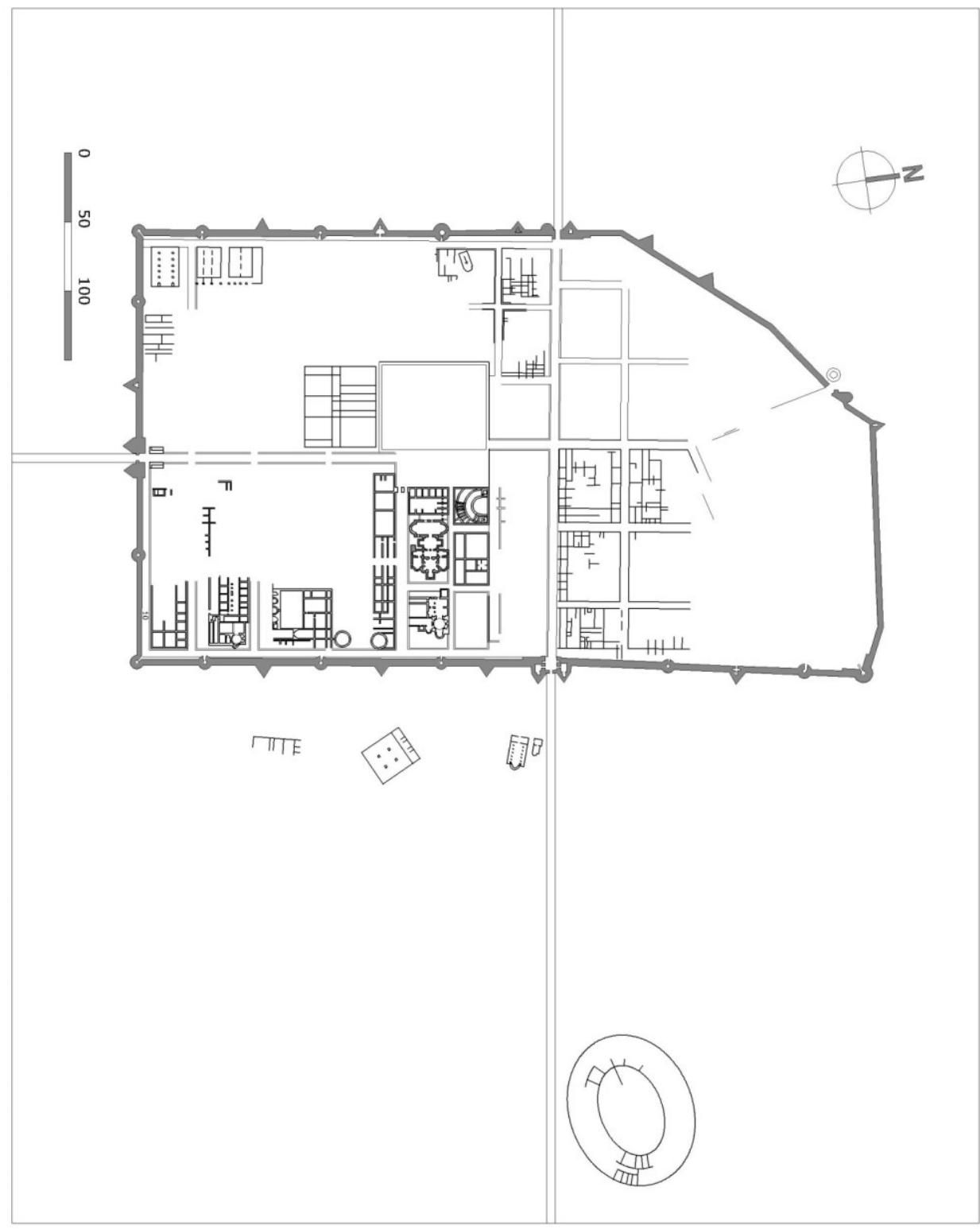

Слика 3. Карта „Старе Сердике”са амфитеатром

(аутор Димитрина Попова према Шалганову 2008) 


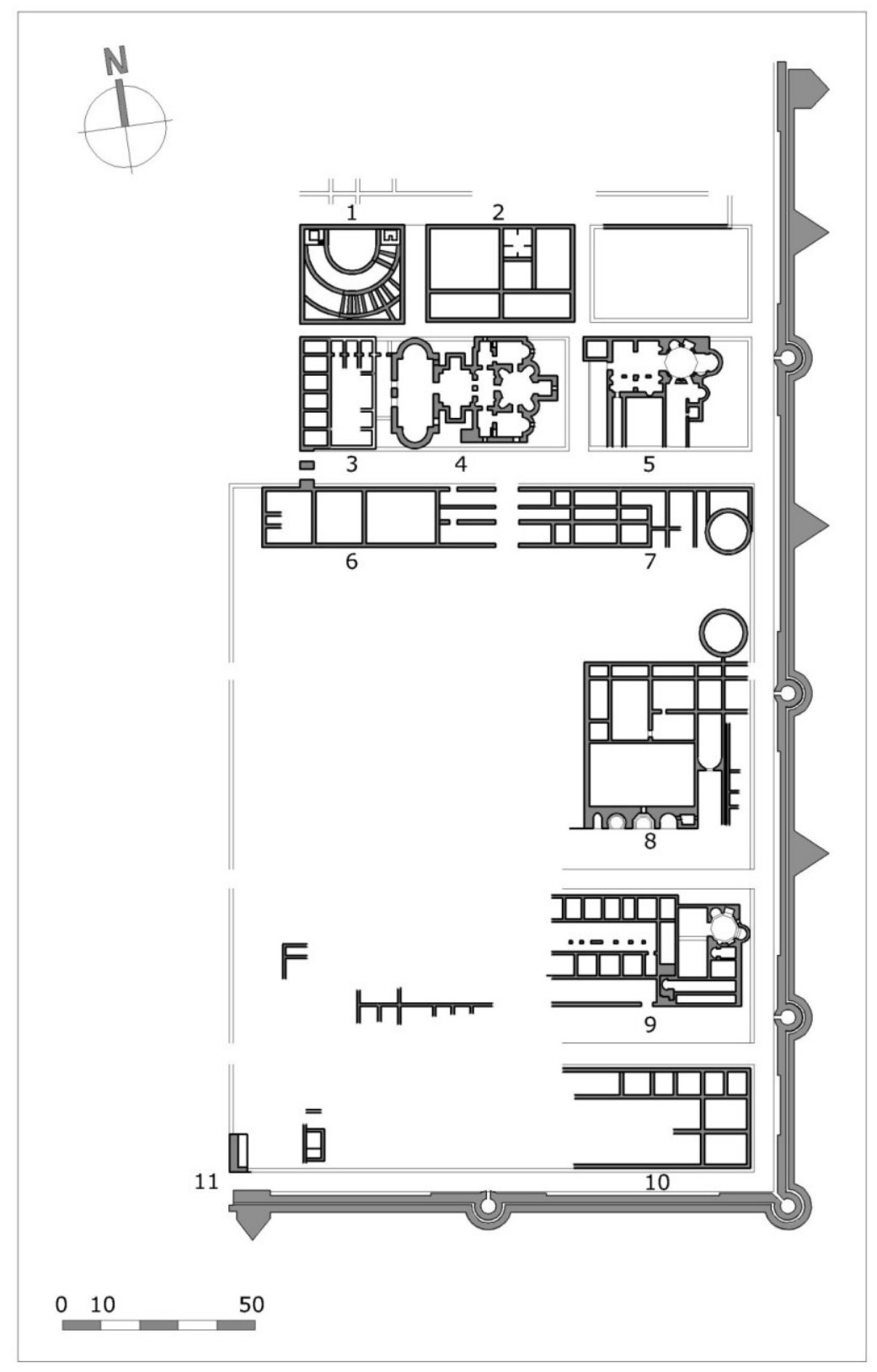

Слика 4. Детаљна карта југоиточне области „Старе Сердике” (аутор Димитрина Попова према Кирину 2000, сл. 4, 15, 20, 62, 63, 72,74 и Кирова 2012, сл. 13) 
ERIC C. DE SENA

\title{
CONSTANTINE IN THE IMPERIAL PALACE AT SERDICA
}

\begin{abstract}
Summary
This paper concerns the presence and activities of Constantine the Great in Serdica as well as in the provinces of Dacia Mediterranea, Dacia Ripensis and Thracia AD 316-330s. The paper begins with a historical overview of Constantine's activities in the region, followed by an archaeological overview of Serdica and other areas within the modern territory of Bulgaria, which Constantine may have had a role in developing. In particular, the question of where the Imperial Palace of Serdica may have been located is addressed.
\end{abstract}

Keywords: Imperial Palace, Constantine the Great, Serdica. 